AT - TADBIR

JURNAL ILMIAH MANAJEMEN

\title{
Consumer Preferences Of Halal-Friendly Hotel Attributes
}

\author{
Fadhila Azhari Shafa*, Rita Komaladewi, Deru R. Indika \\ University of Padjajaran, Bandung \\ Jl. $\mathrm{xxxx}$ \\ e-mail: fadhilaazhari@gmail.com*
}

\begin{abstract}
The rapid growth of halal tourism in Indonesia has increased the need for tourist destinations to offer halal products as a service to the Muslim market. This has an impact on the emergence of business actors' awareness in Indonesia, one of which is a halal-friendly hotel. This study aims to examine consumer preferences for the attributes provided when staying at halal-friendly hotels in the cities of DKI Jakarta and Bandung. This analysis is confirmatory and uses a quantitative approach. Quantitative data collection is done by a survey method that uses an online questionnaire through Google form. Respondents in this study obtained as many as 107 people with the criteria of those who have stayed at least once at a halalfriendly hotel in the cities of DKI Jakarta and Bandung. This analysis was processed using AMOS software version 23. This study considers that there are 4 attributes and 21 indicators that can shape the preferences of consumers staying at halal-friendly hotels. However, the results of this study indicate that the attributes that can shape consumer preferences consist of 4 attributes and 14 indicators, namely halal-friendly service (selection of guest pairs, greetings, uniforms that cover genitals), halal food and beverage (halal food and beverages on restaurants and all outlets, halal logos on the menu), halal-friendly facilities (availability of prayer mats, prayer hijab, qibla direction, worship space, inter-urinal divider), and halal privacy (there are separators of swimming pools and ablutions for male and female guests, single female room service is served by female staff, and vice versa).
\end{abstract}

Keywords: halal friendly hotel attributes, halal hotels, attributes, preferences.

\begin{abstract}
Abstrak
Pesatnya pertumbuhan pariwisata halal di Indonesia telah meningkatkan kebutuhan akan tujuan wisata untuk menawarkan produk-produk halal sebagai layanan ke pasar muslim. Hal itu berimbas dengan bermunculnya kesadaran pelaku-pelaku usaha di Indonesia, salah satunya hotel halal-friendly. Penelitian ini bertujuan untuk mengkaji preferensi konsumen terhadap atribut yang disediakan ketika menginap pada hotel halal-friendly di kota DKI Jakarta dan Bandung. Analisis ini bersifat konfirmatori dan menggunakan metode pendekatan kuantitatif. Pengumpulan data kuantitatif dilakukan dengan metode survei yang menggunakan kuesioner online melalui google form. Responden pada penelitian ini didapat sebanyak 107 orang dengan kriteria yaitu orang-orang yang telah menginap minimal satu kali pada hotel halal-friendly di kota DKI Jakarta dan Bandung. Analisis ini diolah menggunakan software AMOS versi 23. Penelitian ini menganggap bahwa terdapat 4 atribut dan 21 indikator yang dapat membentuk preferensi konsumen menginap pada hotel halal-friendly. Namun, hasil penelitian ini menunjukkan bahwa atribut yang dapat membentuk preferensi konsumen terdiri dari 4 atribut dan 14 indikator yaitu halal-friendly service (penyeleksian tamu berpasangan, pengucapan salam, seragam yang menutupi aurat), halal food and beverage (makanan dan minuman yang halal pada restoran dan semua gerai, logo halal pada menu), halalfriendly facilities (ketersediaan sajadah, mukena, arah kiblat, ruang ibadah, penyekat antar urinoir), dan halal privacy (terdapat pemisah tempat kolam renang dan tempat wudhu untuk tamu pria dan wanita, pelayanan kamar wanita single dilayani oleh staf wanita, begitupun sebaliknya).
\end{abstract}

Kata Kunci : atribut hotel halal-friendly, hotel halal, atribut, preferensi. 


\section{INTRODUCTION}

The Indonesian government has decided that the tourism industry is one of the main important sectors in Indonesia because the tourism industry has become the secondlargest sector of foreign exchange-earners for Indonesia since 2016. Foreign exchange earnings from the national tourism industry can have a large economic impact, due to the tourism industry being classified diverse businesses, ranging from transportation, resorts, hotels, restaurants to SMEs. The development of information and technology has bring the fame of tourism, including the halal tourism into the new era (Abdurrahim \& Zamrudi, 2018).

Until 2019, the Government of Indonesia has shown that Indonesia is focusing on developing the tourism industry. One of the developments carried out is the halal tourism program that has been carried out in the past five years. Halal tourism is one of the Ministry of Tourism's priority programs. Global Muslim Travel Index (GMTI) 2019 data shows that Indonesia obtained the first rank in terms of Access, Communication, Environment, and Services. Indonesia's ranking on the Global Muslim Travel Index (GMTI) has continued to increase in recent years. Indonesia's ranking improvement on the Global Muslim Travel Index (GMTI) reflects that Indonesia is working on developing the halal tourism industry.

GMTI 2019 data also shows that until 2026, the number of Muslim tourists is projected to reach 230 million worldwide and it can also be estimated that Muslim tourists will spend USD \$ 180 billion in 2026 for online travel purchases. In addition, the growth of Indonesia's halal tourism market in 2019 will reach 42 percent. Referring to the achievement target of 20 million foreign tourist arrivals (tourists) that must be achieved in 2019, the Ministry of Tourism is targeting $25 \%$ or equivalent to 5 million of the 20 million foreign tourists who are Muslim tourists.

The rapid growth of halal tourism in Indonesia has increased the need for tourist destinations to offer halal products as a service to the Muslim market. This has an impact on the emergence of business actors' awareness in Indonesia, one of which is a halal-friendly hotel. Halal-friendly hotels are a new niche in the tourism and hospitality sector. This niche area has gained attention among industry, local and foreign players. The State of the Global Islamic Economy Data Report 2018/2019 states that globally the hotel and resort segment is growing rapidly. The global hotel and resort industry reached the US \$ 1 trillion in 2018, growing $2.3 \%$ every year for the past five years, and is expected to reach US $\$ 1.2$ trillion in 2030 .

The development of the global hotel and resort industry is also felt by halal-friendly hotels in Indonesia. This development is supported by public awareness that is starting to develop in applying a halal lifestyle for their needs. It is necessary to know the increasing amount of knowledge, experience, and development in the mindset of the people in this era, the community as consumers can be more selective in choosing and using accommodation services that suit their needs, desires, and comfort. So, the function of a halal-friendly hotel is not only as a public facility that provides lodging for tourists, but also provides a safe and comfortable place if used as a temporary residence. Therefore, it is possible for many people to choose to stay at a halal-friendly hotel.

In this case, to seize the opportunity of the Muslim market, hoteliers must be proactive in attracting Muslim tourists, so that a deeper understanding of the needs, desires, preferences, and specific behavior of Muslim tourists is needed before implementing the best products or services that must be applied. 
As explained by Zamani and Henderson (2010), Muslim tourists tend to follow Islamic rules which can directly or indirectly influence their decisions regarding vacation and travel plans. One reference of the company's orientation towards consumers (especially in the hotel industry) is consumer preferences because consumer preferences aim to continue a marketing strategy that is sustainable so that the goods or services sold or marketed remain in demand by consumers.

Therefore, hoteliers need to pay attention to the attributes in halal-friendly hotels to be offered to tourists, because later it will be the focus and attention in shaping consumer preferences for staying at their hotels.

At this time, in Indonesia, there are still few studies published with the discussion of the analysis of consumer preferences in staying over the attributes of halal-friendly hotels. Therefore, this study aims to examine whether the assessment of the halal-friendly hotel attributes will shape consumer preferences for staying.

\section{Literature Review}

\section{Halal-Friendly Hotel Atributes}

According to Hanjaya, Pranata \& Andreani (2019), the definition of attribute is one of the elements that lead to consumer identification of possible responses to a need. Hotel attributes have an important role in influencing the minds of consumers, especially when determining the choice of accommodation options. Hotels that have superior attributes are better able to win the competition by influencing all critical aspects that are considered by consumers in choosing hotels (Baniya \& Thapa, 2017).

The halal-friendly hotel attribute is a hotel facility that aims to meet the religious needs of consumers where the halal-friendly hotel attribute consists of four attributes, namely: (1) Halal-friendly service, (2) Halal food and beverage, (3) Halal-friendly facilities, and (4) Halal privacy. Additional religious services and provisions at the hotel which will result in the withdrawal of new markets and increased hotel rates.

(1) Halal-friendly service

This attribute pays attention to every halal-friendly service offered by the hotel, such as staff friendliness, how to serve customers, how to dress staff, staff communication, and halal service in the room (Jeaheng, Al-Ansi, \& Han, 2019).

Halal-friendly hotels must also pay attention to how to dress the hotel staff who must cover their genitals, the way hotel staff greet guests, and do not hesitate to reprimand guests who are not Muslims (Mujahidin, 2018).

(2) Halal food and beverage

The availability of halal food is also an important factor in influencing tourists in determining hotel choices to be visited (Putit, Muda, Mahmood, Taufek, \& Wahib, 2016).

This attribute shows that in halalfriendly hotels, care must be taken in terms of food and drink that meets Islamic values or has been certified halal, provided at all food and beverage outlets in the hotel, and shows the halal logo in the food and beverage menu (Jeaheng et al., 2019).

When promoting a tourist destination for Muslim tourists, marketers must carry out promotions that focus on the availability of halal food and drinks (Battour, Ismail, \& Battor, 2011).

(3) Halal-friendly facilities

This attribute pays attention to all facilities provided by the hotel, such as spatial planning, furniture, and hotel decoration, which must comply with Islamic rules (for example there is no picture of a naked human body, and the position of the toilet does not face the Qibla direction), worship space, prayer rug, and prayer hijab, has Qibla direction 
in the room, the hotel does not have a casino or gambling, and the hotel does not have discos and night clubs (Jeaheng et al., 2019).

Halal-friendly hotels pay attention to hotel decorations and ornaments that are in accordance with Islamic values and do not conflict with Islamic teachings. There are worship facilities, prayer rugs, prayer hijab, and the Koran in each room, as well as prayer rooms or mosques around the hotel area. Provides Qibla direction in each hotel room (Mujahidin, 2018).

(4) Halal privacy

This attribute solves the concerns of Muslim consumers regarding privacy issues or characteristics between men and women in the living room or recreation areas of the hotel, such as prayer rooms, gyms, swimming pools, and health centers separated between women and men (Jeaheng et al., 2019).

Halal-friendly hotels must provide privacy for guests at the hotel such as providing sports facilities by separating men and women in one room and providing massage facilities where men can only be massaged by men, and vice versa (Mujahidin, 2018).

This attribute also considers services provided for single female rooms to be serviced by female hotel staff, and single male rooms must be serviced by male hotel staff (Rosenberg \& Choufany, 2009).

\section{Consumer Preferences}

Preference has the meaning of nature which is more emphasized on one's choice of an object that they prefer compared to other objects based on certain factors. Preference is the preferred choice or condition (Al Barry, 2001). Preference is the choice or interest of someone in choosing a product, both goods or services (Simamora, 2013). Consumer preference is the selection of someone's likes or dislikes of the product (goods or services) consumed. Indarto (2011) says that preference is a person's desire to choose an item that can be measured by a scale of needs from the desired product bundle, meaning that every consumer has the right to make an evaluation of the goods and services that really want to be purchased by ranking the product. Understanding consumer preferences aims to continue the marketing strategy that is ongoing so that the goods or services sold or marketed remain in demand by consumers.

There are several previous studies that formulate halal-friendly products. According to Han et al. (2019), the criteria for halalfriendly destinations that affect a visitor's behavioral intention are supported by the social environment of the place, the availability of halal-friendly facilities, services that provide comfort, halal food \& beverages, and the behavior of staff \& residents around. In the context of halalfriendly hospitality, it is not much different from criteria in halal-friendly destinations, attributes that can influence behavioral intentions in halal-friendly hotels are the availability of halal-friendly services, equality in serving Muslim and non-Muslim consumers, the availability of halal food and beverages, there are facilities that support Muslim consumers, and there are separators in certain areas for women and men (such as gyms, spas) (Jeaheng et al., 2019). According to Putit et al. (2016), the attribute of the halalfriendly hotel that greatly influences consumer behavior is the availability of worship facilities. Followed by the other three attributes, namely providing halal food, Islamic dress code, and having Islamic morality. With the existence of halal-friendly attributes that can influence consumer behavior such as making consumers have an interest in staying overnight, consumers can sincerely discuss the object to others (word of 
mouth), and consumers are willing to pay (Jeaheng et al., 2019).

\section{Research Method}

Types of Research

This research is confirmatory which has the main objective to test whether the dimensions or indicators that have been grouped based on latent variables (constructs) are consistent in the constructs or not. The method used in this study is the Second-Order Confirmatory Factor Analysis Method. The Confirmatory Factor Analysis (CFA) method is one of the multivariate analysis methods (describing the influence of two or more variables) that can be used to confirm whether the measurement model that is built is in accordance with the hypothesized (Efendi \& Purnomo, 2012).

\section{Research Location and Time}

The research was carried out online so the results obtained were hotels located in DKI Jakarta (Sofyan Hotel, Zen Room Syariah) and in Bandung (Padma Hotel, Noor, Clove Garden, Cinnamon, Ruby, Airy Syariah, De'qur 'Narapati, elRoyal). This research was conducted for 18 days, starting on January 28, 2020, and ending on February 14, 2020.

\section{Population and Sample}

The population of this study is every person who has stayed at least once at a halalfriendly hotel in the city of DKI Jakarta and the city of Bandung. The sampling technique is done by non-probability side techniques with purposive sampling. The total population is not known with certainty, then in determining the sample size used the formula unknown population, obtained results of 96 respondents. In this study managed to collect data from 107 respondents.

\section{Data Collection Techniques}

Researchers will use two data collection techniques, namely library research (field research) and field studies (field research) to obtain the data needed in this research. For library research (library research) will use several sources such as articles, previous research, books, data reports, and other literature relating to this research topic. While the field research (field research), researchers will collect data using an online questionnaire through Google form which is done by distributing messages personally to respondents who meet the research criteria through social media Instagram. The message is disseminated by: First, look for the halal-friendly hotel Instagram account (example: @noorhotels). Second, click on the 'Photos Tagged' section, then you will see people who have visited the hotel by posting photos related to the hotel. Third, click the account of the person who posted the photo. Fourth, do a 'direct message' and ask the person to fill out an online questionnaire.

\section{Data Analysis}

The analytical method used in this study is based on the objectives of the study, including:

1. Descriptive Analysis

2. Test the Validity and Reliability of the Model

3. Goodness-of-fit Test

4. Hypothesis Test

\section{Results and Discussion}

\section{Result \\ Profile of Respondent}

The total sample in this study was 107 respondents. Respondents consisted of $72.9 \%$ women and $27.1 \%$ men. The age range of the majority of respondents was 20-30 years old or $70.1 \%$ with the majority of respondents' last education being a bachelor or $66.4 \%$ who had the majority of jobs namely $27.1 \%$ private employees and $22.4 \%$ of students. The average respondent has income> Rp. $5,000,000$ or $47.7 \%$. In this study, the majority of respondents staying at halal-friendly hotels stayed at halal-friendly hotels in Jakarta and Bandung on the grounds that they wanted to 
get an atmosphere, service, and facilities that were safe, comfortable, and clean.

\section{Goodness-of-fit Test}

In doing SEM modeling, it will evaluate the feasibility criteria of the model with the aim of assessing whether the data processed meets the structural model assumptions, seeing whether there are any offending estimates and assessing the overall model fit with various existing criteria. Testing the accuracy of this model uses goodness-of-fit which aims to determine the extent to which the model is hypothesized 'fit' or match the data sample.

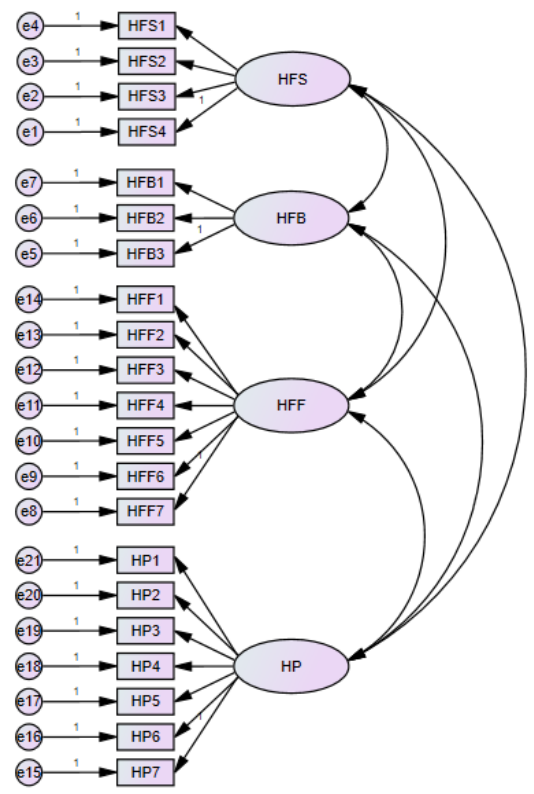

Pictures 1. SEM Model Between Dimensions Source: data processed, 2020

Table 1. Goodness-of-Fit Results

\begin{tabular}{cccc}
\hline $\begin{array}{c}\text { Goodness-of-Fit } \\
\text { Indices }\end{array}$ & Cut of Value & Analysis Results & $\begin{array}{c}\text { Model } \\
\text { Description }\end{array}$ \\
\hline Chi-Square & p-value $\geq 0,05$ & 0,000 & Less fit \\
\hline RMSEA & $\leq 0,08$ & 0,127 & Less fit \\
\hline GFI & $\geq 0,90$ & 0,661 & Less fit \\
\hline AGFI & $\geq 0,90$ & 0,572 & Less fit \\
\hline CMIN/DF & $\leq 2,00$ & 2,720 & Less fit \\
\hline TLI & $\geq 0,90$ & 0,833 & Marginal Fit \\
\hline CFI & $\geq 0,90$ & 0,854 & Marginal Fit \\
\hline
\end{tabular}

Source: data processed, 2020

Table 1 shows that the final model formed does not meet all Goodness-of-Fit (GOF) statistical criteria such as p-value, RMSEA, GFI, AGFI, and CMIN / DF, so that the measurement model does not meet the criteria of a good measurement model (fit) and can be used as a manifest for the formation of a full model. Therefore, to make 
the research model of the dimension of halalfriendly facilities fit, a reduction or reduction in question items is needed. This reduction process is carried out by the rules of the AMOS software version 23, namely by reducing the value of the highest modification indices, so we get a dimension research model that has been fit in accordance with Picture 2 below.

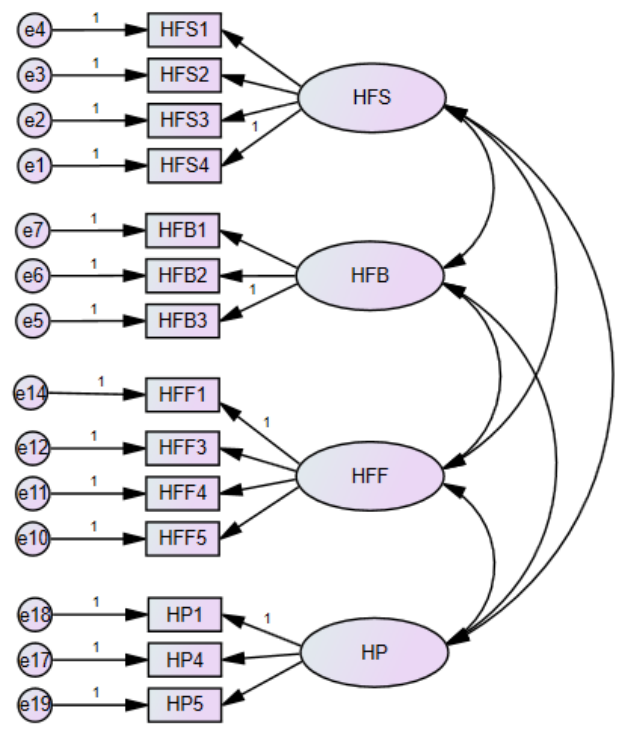

Pictures 2. SEM Model Between Dimensions After Reduction Source: data processed, 2020

Table 2. Goodness-of-Fit Results After Reduction

\begin{tabular}{cccc}
\hline $\begin{array}{c}\text { Goodness-of-Fit } \\
\text { Indices }\end{array}$ & Cut of Value & $\begin{array}{c}\text { Analysis } \\
\text { Results }\end{array}$ & $\begin{array}{c}\text { Model } \\
\text { Description }\end{array}$ \\
\hline Chi-Square & p-value $\geq 0,05$ & 0,000 & Less fit \\
\hline RMSEA & $\leq 0,08$ & 0,087 & Marginal Fit \\
\hline GFI & $\geq 0,90$ & 0,847 & Marginal Fit \\
\hline AGFI & $\geq 0,90$ & 0,773 & Marginal Fit \\
\hline CMIN/DF & $\leq 2,00$ & 1,795 & Fit \\
\hline TLI & $\geq 0,90$ & 0,942 & Fit \\
\hline CFI & $\geq 0,90$ & 0,955 & Fit
\end{tabular}

Source: data processed, 2020

Table 2 above shows that the final model formed has fulfilled the Goodness-of-Fit (GOF) statistical criteria such as RMSEA, GFI, AGFI, CMIN / DF, TLI, and CFI, while those that do not meet the model's fit requirements are only chi-square values. Hair, et al., (2014) explained that chi-square is very sensitive to the large sample used, so it must be accompanied by other test equipment. This study used a sample of 107 respondents so that the chi-square values could not be considered valid because the other six index criteria tested had met the suitability of the model.

After testing the goodness-of-fit on all four dimensions, it can be concluded that of the 21 indicators there are 14 indicators that are eligible to be tested for hypotheses to 
become consumers' preferences for halalreceived are listed in table 3 below. friendly hotel attributes. The indicators

Table 3. Interpretation of the Overall Goodness-of-Fit Test

\begin{tabular}{|c|c|c|}
\hline Code & Indicators & Description \\
\hline \multicolumn{3}{|c|}{ Halal-Friendly Service } \\
\hline HFS1 & Greetings to new guests & Accepted \\
\hline HFS2 & Polite uniforms (covering genitals) & Accepted \\
\hline HFS3 & Selection of guests who come in pairs & Accepted \\
\hline HFS4 & Good and friendly service for Muslim and non-Muslim guests & Accepted \\
\hline \multicolumn{3}{|c|}{ Halal Food and Beverage } \\
\hline HFB1 & Provision of halal food and beverages & Accepted \\
\hline HFB2 & $\begin{array}{l}\text { Provision of halal food and beverages in all food and beverage outlets (e.g. rooms, } \\
\text { coffee shops) }\end{array}$ & Accepted \\
\hline HFB3 & Provision of halal logos on food and beverage menus & Accepted \\
\hline \multicolumn{3}{|c|}{$\begin{array}{ll}\text { Halal-Friendly Facilities } \\
\end{array}$} \\
\hline HFF1 & Provision of praying room & Accepted \\
\hline HFF2 & Provision of ablution facilities & Rejected \\
\hline HFF3 & Provision of prayer rugs / prayer hijab & Accepted \\
\hline HFF4 & Provision of Qibla direction in hotel rooms & Accepted \\
\hline HFF5 & Provision of insulation between one urinal and another urinal in a public toilet & Accepted \\
\hline HFF6 & Provision of closed bathrooms (e.g. not from see-through glass) & Rejected \\
\hline HFF7 & $\begin{array}{l}\text { The absence of facilities that deviate from Islamic principles (e.g. casinos, gambling, } \\
\text { discotheques, night clubs) }\end{array}$ & Rejected \\
\hline \multicolumn{3}{|c|}{ Halal Privacy } \\
\hline HP1 & Provision of separate swimming pools between male and female guests & Accepted \\
\hline HP2 & Provision of separate gym rooms between male and female guests & Rejected \\
\hline HP3 & Provision of separate spa rooms between male and female guests & Rejected \\
\hline HP4 & Provision of separate ablution places between male and female guests & Accepted \\
\hline HP5 & Services provided for single female rooms are served by female staff, and vice versa. & Accepted \\
\hline HP6 & Male spa therapists specifically for men and women exclusively for women & Rejected \\
\hline HP7 & There are floor separators for single men, single women and families & Rejected \\
\hline
\end{tabular}

Source: data processed, 2020

\section{Hypothesis Testing}

To find out whether the hypothesis is supported by data or not, then the criterion value of the Critical Ratio (C.R) $\geq 2.58$ at the significance level of $1 \%$, or the Critical Ratio (C.R) $\geq 1.96$ at the significance level of $5 \%$. Based on statistical analysis using the AMOS version 23 program, obtained the results of the hypothesis test as presented in the table 4.

Based on table 4 can be obtained that:

H1: Halal-friendly service attributes that shape consumer stay preferences at halalfriendly hotels.
The test results in table 4 show that the pvalue on the halal-friendly service attribute is 0,000 significant at the significance level of $p$ $\leq 0.05$, so it can be concluded that hypothesis 1 is accepted.

Table 4 also shows that the halal-friendly service attribute consists of 4 indicators that can form a stay preference, namely (1) greetings to new guests, (2) wearing polite uniforms (covering genitals), (3) selecting the guests who come in pairs, and (4) Good and friendly service for Muslim and nonMuslim guests. 
H2: Halal food and beverage attributes that shape consumer stay preferences at halalfriendly hotels.

The test results in table 4 show the p-value of the halal food and beverage attributes of 0,000 is significant at the significance level of $p \leq 0.05$, it can be concluded that hypothesis 2 is accepted.

Table 4 also shows that the attributes of halal food and beverage consist of 3 indicators that can form a stay preference, namely (1) Provision of halal food and beverages, (2) Provision of halal food and beverages in all food and beverage outlets (eg rooms, coffee shop), and (3) Provision of halal logos on food and beverage menus.

H3: Halal-friendly facilities attributes that shape consumer stay preferences at halalfriendly hotels.

The test results in table 4 show that the pvalue on the halal-friendly facilities attribute is 0,000 significant at the significance level of $p \leq 0.05$, so it can be concluded that hypothesis 3 is accepted.

Table 4 also shows that the attribute of halal-friendly facilities consists of 4 indicators that can form a stay preference, namely (1) Provision of worship space, (2) Provision of prayer rugs/prayer hijab, (3) Provision of Qibla direction in hotel rooms, and (4) Provision of insulation between one urinal with another urinal in a public toilet.

H4: Halal privacy attributes that shape consumer stay preferences at halal-friendly hotels.

The test results in table 4 show the p-value on the halal privacy attribute of 0,000 is significant at the significance level of $\mathrm{p} \leq$ 0.05 , it can be concluded that hypothesis 4 is accepted.

Table 4 also shows that the halal privacy attribute consists of 3 indicators that can form a stay preference, namely (1) Provision of separate swimming pools between male and female guests, (2) Provision of separate ablution places between male and female guests, and ( 3) Services provided for single female rooms are served by female staff, and vice versa.

\section{Discussion}

Based on research descriptions and explanations that have been described previously, consumer preferences in staying in halal-friendly hotels have their respective values. The results of consumer preferences can be a reference for the halal-friendly hospitality industry to improve the attributes that are considered to be able to support the needs of consumers when staying in a halalfriendly hotel.

From the results of the analysis of preferences that the authors do regarding the attributes of a halal-friendly hotel, it can be concluded that from the initial 21 factors considered to affect consumer preferences there are only 14 factors out of 4 attributes, namely; (1) halal-friendly service consists of 4 indicators, (2) halal food and beverage consists of 3 indicators, (3) halal-friendly facilities consist of 4 indicators, and (4) halal privacy consists of 3 indicators.

These attributes must be considered in order to improve the quality of halal-friendly hotels, but do not make other attributes excluded because it requires a balance between all facilities and stakeholders so that halal-friendly hotels can develop.

\section{Conclussion}

\section{Conclusions}

Based on the results of research and discussion related to the analysis of consumer preferences for halal-friendly hotel attributes. Then it can be concluded that the halal-friendly hotel must prioritize attributes that are used by consumers as a preference in choosing a hotel so that the halal-friendly hotel is easier to attract 
consumers who will later increase the number of consumers and increase the amount of company revenue. The attributes that are used as consumer preferences are:

Halal-friendly service attribute. In this attribute, there are 4 factors, namely: (1) Selection of guests who come in pairs, (2) Greetings to new guests, (3) Use of polite uniforms (covering genitals), and (4) Good service and friendly to Muslim and nonMuslim guests.

Halal food and beverage attributes. In this attribute, there are 3 factors, namely: (1) Provision of halal food and beverages, (2) Provision of food and beverages in all food and beverage outlets, and (3) Presence of a halal logo on the food and beverage menu.

Halal-friendly facilities attributes. In this attribute, there are 4 factors, namely: (1) Provision of prayer rugs and prayer hijab, (2) Provision of Qibla direction, (3) Provision of worship space, and (4) Provision of insulation between one urinal and another urinal in a hotel public toilet.

Halal privacy attribute. In this attribute, there are 3 factors, namely: (1) There is a separation of the swimming pool between male and female guests, (2) There is a separation of floor rooms for single men, single women, and families, and (4) Services provided for female rooms singles are served by female staff, and vice versa.

\section{Suggestions}

Based on the results of the study, the researchers have suggestions for halal-friendly hoteliers. Some suggestions that can be explained are halal-friendly hoteliers who can provide facilities that support the comfort and safety of consumers to stay at their hotels.

From the halal-friendly service attribute, the hotel should be able to select guests who come in pairs by checking whether the guest has a marriage certificate or marital status attached to the National Identity Card (KTP) so that it can be mapped which ones should be combined and which rooms should be separated -his. This can be applied by the hotel after socializing these rules or displaying posters in front of the receptionist. The halal-friendly hotel must also train and make SOP (Standard Operating Procedures) for its employees to be able to serve consumers in a directed and orderly manner by always saying "assalamualaikum" when guests arrive (especially for receptionists and security guards), paying attention in terms of clothes must cover their nakedness, and must be kind and friendly to all hotel guests without discriminating their identity.

From the halal food and beverage attributes, the hotel must provide halal food and drinks so that it can be consumed by all hotel guests, and create confidence in hotel guests that the food and drinks at the hotel are halal. The hotel should also provide a halal logo on the menu served to guests. This can give guests confidence in the food and drinks that they will consume halal.

From the halal-friendly facilities attribute, the hotel should provide facilities that can support hotel guests to worship, such as providing prayer mats and prayer hijab in every hotel room, providing Qibla direction in each hotel room, providing worship space, and the hotel should also pay attention in men's public toilets whether there is a divider between one urinal and another urinal. These things can provide peace and comfort to hotel guests.

From the halal-privacy attribute, if the hotel has a swimming pool the hotel should be able to make a separation between female and male guests. The hotel should also pay attention to the public ablution space provided, preferably placed separately for female and male guests. The hotel should also differentiate services for single female rooms that must be served by female staff as well, and vice versa. It aims to provide security for guests in order to maintain personal matters. 


\section{References}

Abdurrahim, A., \& Zakky, Z. (2018). WISATAWAN DIGITAL: PERAN MEDIA SOSIAL DALAM MEMBENTUK MINAT BERWISATA. At-Tadbir: jurnal ilmiah manajemen, 2(2).

Al Barry, M. Dahlan. (2001). Kamus Imiyah Populer, Yogyakarta: Arkola Surabaya.

Baniya, R., \& Thapa, P. (2017). Hotel Attributes Infl uencing International Tourists' Satisfaction and Loyalty.

Battour, M., Ismail, M. N., \& Battor, M. (2011). The impact of destination attributes on Muslim tourist's choice. International Journal of Tourism Research, 13(6), 527-540. https://doi.org/10.1002/jtr.824

Efendi, M. M., \& Purnomo, J. D. T. (2012). Analisis Faktor Konfirmatori untuk Mengetahui Kesadaran Berlalu Lintas Pengendara Sepeda Motor di Surabaya Timur. Fakultas Matematika Dan Ilmu Pengetahuan Alam, Institut Teknologi Sepuluh Nopember (ITS), 1(1), D106D111. Retrieved from http://ejurnal.its.ac.id/index.php/sains_se ni/article/download/

Hanjaya, S., Pranata, M. D., \& Andreani, F. (2019). Pengaruh Atribut Hotel Butik Terhadap Minat Menginap Kembali Dengan Kepuasan Konsumen Sebagai Variabel Perantara Di Surabaya. Jurnal Manajemen Perhotelan, 5(1), 18-25. https://doi.org/10.9744/jmp.5.1.18-25 Indarto, R.P. (2011). Analisis Preferensi Konsumen Terhadap Bundling Kartu GSM dengan Smartphone. (Thesis): Universitas Indonesia
Jeaheng, Y., Al-Ansi, A., \& Han, H. (2019). Halal-friendly hotels: impact of halalfriendly attributes on guest purchase behaviors in the Thailand hotel industry. Journal of Travel \& Tourism Marketing, 36(6), 729-746.

https://doi.org/10.1080/10548408.2019.1 631940

Mastercard \& CrescentRating. (2019). Global Muslim Treval Index 2019 (GMTI 2019)

Mujahidin, M. (2018). Sharia hotels in Indonesia : Concept and potential analysis. (90819).

Putit, L., Muda, M., Mahmood, A. N., Taufek, N. Z. A., \& Wahib, N. (2016). Linking'Halal'Friendly Hotel Attributes and Customer Satisfaction: The Islamic Tourism Sector. Journal of Emerging Economies \& Islamic Research, 4(2010).

Rosenberg, P., \& Choufany, H. M. (2009).

Spiritual Lodging - the Sharia Compliant Hotel Concept. HVS Global Hospitality Services- Dubai, (April), 17.

Simamora, Henry. (2013). Panduan Perilaku Konsumen. Jakarta: Gramedia.

Thomson Routers, I. C. with D. S. (2019).

State of the Global Islamic Economy 2018/2019 Report.

Zamani-Farahani, H., Henderson, J.C. (2010). Islamic Tourism and Managing Tourism Development in Islamic Societies: The Cases of Iran and Saudi Arabia. International Journal of Tourism Research 